\title{
The Papers of Dorothy Mary Crowfoot Hodgkin
}

\author{
National Cataloguing Unit For The ARchives Of Contemporary Scientists
}

\author{
University of Bath, Claverton Down, Bath BA2 7AY, England
}

Dorothy Mary Crowfoot was born in Cairo in 1910 and educated at the Sir John Leman School, Beccles, and Somerville College, Oxford where she read chemistry 1928-1932. Apart from two years research at Cambridge University after graduation she remained in Oxford for the rest of her career. Here for 25 years she combined teaching chemistry at Somerville, where her students included the future Prime Minister Margaret Thatcher, with research at the highest level. She became University lecturer and demonstrator in 1946, University Reader in X-ray crystallography in 1956, and from 1960 to official retirement in 1977 Wolfson Research Professor of the Royal Society. In 1937 she married Thomas Lionel Hodgkin with whom she had three children.

Dorothy Hodgkin carried out her first research at Oxford in 1931-1932 with H. M. Powell on the structure of thallium dialkyl halides. She then went to Cambridge to work for two years with J. D. Bernal who had just been appointed to start research on the study of crystals by X-ray diffraction and had begun to look at biologically interesting molecules. The research at Cambridge included work on sterols, vitamin B1 and the protein pepsin, and on her return to Oxford she decided to concentrate on one crystal structure in detail and (with C. H. Carlisle) correctly analysed cholesterol iodide, the first complex organic molecule to be determined completely by X-ray crystallography. Early in the Second World War the successful tests with penicillin extracts on infected mice by Howard Florey and his team in Oxford led to urgent attempts to determine its chemical structure. Hodgkin and her coworkers accomplished this in three years with X-ray techniques, showing conclusively that the formula of penicillin included $\beta$ lactam and thiazolidine rings. She later elucidated the structure of cephalosporin C, an antibiotic closely related to penicillin. After 1948 Hodgkin began work on the $\mathrm{X}$-ray analysis of the anti-pernicious anaemia factor vitamin B12. The red crystals of B12 were supplied by E. L. Smith of Glaxo Laboratories and after a lengthy step-by-step analysis lasting nearly ten years she and her team found the structure. The processing of data was aided by three of the first electronic computers located at Manchester University, the National Physical Laboratory, Teddington, and the University of California, Los Angeles, and Hodgkin played a leading part in the campaign to provide computer facilities at Oxford University. After the success of the vitamin B12 work Hodgkin and her team refocused their research effort on the crystal structure of insulin - she had taken the first X-ray photographs of insulin crystals in 1935 - and were able to announce the three-dimensional structure of rhombohedral $2 \mathrm{Zn}$ insulin in 1969. Research on insulin refinements continued into the 1980 s.

Apart from her scientific research career at Oxford University, Hodgkin undertook a number of prominent public and professional responsibilities including in the UK, Chancellor of Bristol University, 1970-1988, and President of the British Association for the Advancement of Science, 1977-1978, and internationally, President of the International Union of Crystallography, 19721975. Hodgkin's involvement in humanitarian and peace issues was given impetus by the Vietnam War. She became Vice President of the Medical Aid Committee for Vietnam in 1965 and President in 1971, visiting North Vietnam in 1971 and 1974. Her second major commitment in the area of peace and international understanding was to the Pugwash movement (Pugwash Conferences on Science and World Affairs), which she served as President, 1976-1988.

Hodgkin was elected FRS in 1947 (Royal Medal 1956, Copley Medal 1976; Tercentenary Lecture 1960, Bakerian Lecture 1972), and was awarded the Nobel Prize in Chemistry in 1964 for her determinations by $\mathrm{X}$-ray techniques of the structures of important biochemical substances. In 1965 she became only the second woman to be appointed to the Order of Merit.

The papers of Dorothy Hodgkin provide a very full record of her career, research and wider professional and public responsibilities. Biographical material includes records of Hodgkin's career, honours and awards, 1928-1990, including documentation of the award of the Nobel Prize, later family and personal correspondence and drafts of an unfinished autobiography. Research material forms by far the largest component in the collection and comprises very extensive documentation of the major topics of insulin, penicillin and vitamin B 12 covering a period of 60 years from about 1928 to 1988. Most of the material was found in Hodgkin's box folders whose contents included correspondence, drafts for reports and publications, notebooks, notes and data. J. D. Bernal, with whom Hodgkin worked in Cambridge 1932-1934, and very many of her later collaborators including C. W. Bunn (penicillin) and E. L. Smith (vitamin B12) are represented in the papers by correspondence, drafts, notes and data. Although not extensive there is useful documentation of Hodgkin's 
Oxford University career including teaching in the 1940's and 1950's, her tenure of the Wolfson Research Professorship of the Royal Society, 1960-1977, the funding and administration of her research and the provision of equipment and supplies including the use of computer facilities at other institutions in the UK and USA and their development at Oxford. There are chronological sequences of material relating to Hodgkin's scientific publications and public lectures and substantial assemblages of material relating to her Royal Society memoirs of J. D. Bernal and Kathleen Lonsdale. There is documentation of Hodgkin's involvement with 16 British and international societies and organisations including Bristol University, the British Association for the Advancement ${ }_{w}$ of Science, the Institute of Physics, especially its X-ray Analysis Group established 1943, the International Union of Crystallography and the Royal Society. Her major commitments to Bristol University, where she was Chancellor for nearly 20 years, and to the International Union, which she served as President and whose congresses - she attended 1948-1993, are particularly well documented. There is a chronological sequence of material relating to Hodgkin's scientific visits and conferences, 1936-1993, though the great bulk of the material is from the period after the award of the Nobel Prize in 1964. There is evidence for example of her interest in maintaining scientific contacts with the USSR and China during the Cold War and of visa difficulties in respect of visiting the USA during the same period. There is also documentation of the wide range of peace and humanitarian causes with which Hodgkin was involved. Represented are her major commitments to the Medical Aid Committee for Vietnam and the Pugwash movement and other organisations and topics including the J. D. Bernal Peace Library, Palestine, Russian dissidents and Scientists Against Nuclear Arms (SANA). There is an extensive scientific correspondence in which many of her distinguished mentors and contemporaries are represented such as J. D. Bernal, W. L. Bragg, J. W. Cornforth, P. P. Ewald, I. Fankuchen, H. Lipson, Kathleen Lonsdale, A. L. Patterson, Linus Pauling, M. F. Perutz, Robert Robinson, R. L. M. Synge and Dorothy Wrinch, and very many of the younger scientists from Britain and overseas who researched in various capacities in her laboratory. The sequence is also noteworthy for the significant number of women scientists who trained in Hodgkin's laboratory. Non-textual material in the collection includes photographs, photographic slides and sound recordings. There are photographs of Hodgkin and scientific colleagues including J. D. Bernal, I. Fankuchen, H. M. Powell and other colleagues from the Oxford laboratory, P. L. Kapitza and F. H. C. Crick, a photograph album recording Pugwash occasions, 1969-1988, photographic slides for Hodgkin's lectures especially on insulin and vitamin B12 and sound recordings including the 1973 Nobel Guest Lecture and her Chancellor's Address to the Bristol University Education Department in 1974.

Papers of Hodgkin's parents John Winter and Grace Mary Crowfoot and her husband Thomas Lionel Hodgkin are retained in family hands. Videotape interviews of Hodgkin are held in the Archives of the Biochemical Society and the Library of the Royal College of Physicians, London. Two models showing the crystal structure of vitamin B12 and two models made by Hodgkin to show the structure of pig insulin at a resolution of $2.8 \AA$ are held by the Science Museum. London. Drawings of Hodgkin's hands by Henry Moore and a portrait of her by Bryan Organ are held by the Royal Society, London. A portrait by Maggi Hambling was commissioned for the National Portrait Gallery, London.

This account of the cataloguing of the papers of Professor Dorothy Crowfoot Hodgkin was prepared by the National Cataloguing Unit for the Archives of Contemporary Scientists. It is reproduced here by permission. The cataloguing of Professor Hodgkin's papers was undertaken at the University of Bath by the NCUACS for deposit in the Bodleian Library, Oxford. This work was funded for two years by the Leverhulme Trust. We thank Mr Peter Harper, Archivist at NCUACS, and Dr C. K. Prout of Oxford University, for facilitating this publication in Acta Crystallographica. 